\title{
The Effectiveness of Simultaneous Prompting in the Teaching of Towel Folding Skills for Students with Intellectual Disabilities
}

\author{
Zehra Atbaş1 ${ }^{1} \&$ Tuğba Pürsün ${ }^{1, *}$ \\ ${ }^{1}$ Necmettin Erbakan University, Konya, Turkey \\ *Correspondence: Necmettin Erbakan University, Konya, Turkey. Tel: 90-542-310-7548. E-mail: \\ tugbapursun@gmail.com
}

Received: June 4, 2020

Accepted: July 4, $2020 \quad$ Online Published: July 21, 2020

doi:10.5430/wje.v10n4p15

URL: https://doi.org/10.5430/wje.v10n4p15

\begin{abstract}
The aim of this research was to study the effectiveness of teaching with the simultaneous prompting in teaching students with intellectual disabilities attending the vocational education center and their ability to fold towels. Multiple baseline models with inter-subject probe stage, which is one of the single-subject research methods, has been used. The subjects of the research are three students, one female and two males, between the ages of 16-18. The dependent variable of the study was determined as the ability to fold the towel and the independent variable as the teaching with the simultaneous prompting using the physical prompt as a model + verbal prompt and error correction. In the study, inter-observer reliability and procedural reliability data were collected. Graphical analysis was used to determine the effectiveness of teaching with the simultaneous prompting. According to the findings obtained from the research, simultaneous prompting teaching is effective in teaching students with intellectual disabilities the ability to fold towels. It has been observed that the skill of folding towels into shapes continues to last two, three, and four weeks after the end of the education and that the subjects can generalize the skill in different types of towels.
\end{abstract}

Keywords: intellectual disability, simultaneous prompting teaching, skill teaching, shaped towel folding

\section{Introduction}

The main goal of educational programs for individuals with intellectual disabilities is to teach these individuals the skills they need to prepare them for social life and to maintain their lives independently or with the least dependence (Diken, 2015). The transition to social life after school is generally grouped under three main headings: job / vocational preparation skills, social/independent life skills, and functional academic skills (Sucuoglu, 2012). Functionality is aimed at firstly in academic skill programs prepared for individuals with intellectual disabilities. Functional education programs include skills in various fields such as money management, socialization, self-esteem, employment skills, traveling, and participation in social life, home life, self-care, cleaning, health, and safety (Wehmen \& Kregel, 2004). To ensure that individuals with disabilities in functional education programs are at the highest level of independence, the skills needed for the individual should be taught in a meaningful way. Winn and Hay (2009) state that the employability skills that individuals need to ensure a job placement can be gained with the help of academic programs in schools and workplaces.

The transition of young adults to the labor market after completing their education life is of great importance for both the individual and the society. Having a profession provides various opportunities such as obtaining a social environment, obtaining economic income, increasing the level of welfare, and quality of life. Individuals with disabilities get more opportunities to gain independence and social integration when they have a profession (Brady \& Rosenberg, 2002). When evaluated from a social perspective, the decrease in the number of unemployment benefits contributes to the economy in general (Jacob, Scott, Falkner, \& Falkner, 2015). Business skills, which are the first step of individuals in their transition to adult life, are considered as a skill they need to learn independently when evaluated regarding individuals with special needs. The acquisition of these skills can be the first step of being productive for individuals with disabilities.

According to AAMR (2002), job skills consist of necessary skills such as part-time or full-time work at a job, performing job tasks, and following the work schedule. Individuals with disabilities can fulfill these skills by having 
different experiences about the job they will work with. Work experience contributes to the development of the interpersonal relationships and work habits required for the individual to get and maintain a job (Sucuoglu, 2012). The acquisition of work-oriented skills requires vocational training. Vocational education focuses on the fact that individuals with disabilities are useful and productive individuals in different jobs according to their abilities. Therefore, vocational education is seen as an effective tool for the inclusion of individuals with intellectual disabilities in the labor market (Myklebust, 2013), as well as having positive technical and social effects for the improvement and development of life routines.

Acquisition of professional skills enables individuals to experience increased self-esteem by increasing professional opportunities, being able to earn money, and contributing to a common goal with their colleagues (Maciag, Schuster, Collins, \& Cooper, 2000). Research results show that it provides other benefits such as providing a high job satisfaction, self-esteem, free will, and increased social interaction in the community (Lewis, Thoresen, \& Cocks, 2011). However, having an idea that an individual with a disability cannot work can be more important for individuals with disabilities because in many areas, the quality of life of the individual decreases, the person becomes dependent on others, and his self-confidence decreases (Avcioglu, 2018).

Intellectual disability is characterized by significant limitations in both mental functionality and adaptive behaviors, as expressed in conceptual, social, and practical adaptability skills (Diken \& Bakkaloglu, 2016; Schalok, Luckasson, \& Shogren, 2007), individuals are negatively affected in various ways such as discrimination. Kroese, Kuljit, and O'Brien (2013) state that employees with disabilities are more likely to encounter poverty, short-term employment, unemployment, and social exclusion even in cases where discrimination is reduced. It is difficult for individuals with intellectual disabilities to get a job after completing their school life due to the lack of employment policy related to these individuals, their communication skills and lack of work experience as well as their attitudes in business life (Wehman, 1996).

For individuals with intellectual disabilities, both starting and maintaining work emerges as a challenge. Since job opportunities are generally not sufficient for individuals with special needs, the definition of their interests, skills, personal characteristics, learning styles, and professional competencies enable the professional orientation to be made appropriately (Ministry of National Education, 2013). Information technologies, office management, crafts, food technology, clothing technology, beauty, and hair care technology, construction technology, chemical technology, accommodation services, printing technology, metal technology, furniture, and interior design, motorized for individuals with mental disabilities' vehicle technology, ceramic and glass technology, agriculture, textile technology, installation technology, and food and beverage services are included (Ministry of National Education, 2018). One of the business areas that facilitate employment by providing a job opportunity to individuals with intellectual disabilities is hotel management. It is aimed to raise individuals with intellectual disabilities who are directed to accommodation services in vocational education centers as housekeeping staff, and individuals who attend these departments have increased opportunities to find a job in the hotel industry. When individuals with intellectual disabilities start working in the housekeeping department, they are assigned as room attendants, challengers, material carriers, towel dispensers, washers, and ironers. Disabled individuals working as housekeepers in housekeeping have duties and responsibilities such as complying to the hygiene rules following the orders received from his supervisor, to clean the areas under his responsibility (rooms, corridors, bathrooms, offices) to the desired standard and to report the malfunctions to hand over the forgotten items to his supervisor, to deal with the guest requests and complaints following the rules to change the room and to make the extra bed. (Ministry of National Education, 2007).

Various methods are used to acquire professional skills to individuals with intellectual disabilities. To provide a systematic education to these individuals, the information, concept, or skill required to be acquired by the individual should be presented individually (Avcioglu, 2018). For this, after deciding what to teach the individual, how to teach it is determined. After selecting the skill to be taught to the individual, the first step is to determine the student's level of performance; the next stage after determining the performance level is the determination of the goals (Avcioglu, 2018; Tekin, 1996). Errorless teaching methods are one of the ways of teaching effective and productive individuals with intellectual disabilities (Tekin, 2000). Accurate teaching is an approach based on the assumption that learning the skills and concepts in the best way occurs not through mistakes made during teaching, but through positive responses and exercises during teaching (Tekin-Iftar \& Kurcaali-Iftar, 2017). Errorless teaching methods are divided into two as based on stimulus prompts and response prompts and teaching with the simultaneous prompting which is one of the responses prompts methods provides effective teaching of many concepts and skills (Odluyurt, 2015).

With the simultaneous prompting, the teaching target is to present the controller prompt following the stimulus, and 
the individual takes this prompt as a model and reacts correctly. At the same time, probe sessions are organized to determine whether learning takes place in teaching. Probe sessions can be held on the same day immediately after the teaching sessions or just before the teaching sessions (Odluyurt, 2015). Simultaneous prompting teaching is carried out as a 0 -second waiting period trial of fixed waiting period education. During the teaching process, the individual is presented with a target stimulus and a controlling prompt is given immediately. The individual takes the controller prompt as a model. Each trial includes a target stimulus and a controller prompt. Therefore, the individual does not have the opportunity to react independently (Tekin-Iftar \& Kırcaali-Iftar, 2017).

There are three types of individual responses in teaching with a simultaneous prompting: a) right responses, b) wrong responses, c) no reaction. The practitioner should decide how to react to the individual's reactions in the event of each of these three reactions before starting education (Tekin-Iftar \& Kircaali-Iftar, 2017). There are two types of wrong reactions in the teaching method with the simultaneous prompting, namely wrong reaction, and no reaction. In these cases, the practitioner can make error correction by presenting the skill instruction again, eliminating the target stimulus, presenting the new experiment, and presenting the controller prompt for the correct response (Tekin \& Kircaali-Iftar, 2001).

When the researches are examined, having the individuals with intellectual disabilities do the photocopying (Yucesoy Ozkan \& Gursel, 2006); preparing a dining table (Uçar Rasmussen \& Çifci Tekinarslan, 2017); stitching and embroidery (Aslan \& Eratay, 2009); making over- shoes (Leblebici, 2012); knitting (Çankaya, 2011); lawn mowing (Aslan, 2009); Simultaneous prompting method is used in teaching car wash skills (Topsakal \& Duzkantar, 2010). However, in the housekeeping department, which is one of the business areas of individuals with intellectual disabilities, there is no study related to the teaching of shaped towel folding skills, which is one of the skills those individuals who are responsible for room services should have. Since individuals with intellectual disabilities in-room services should have acquired this skill correctly and permanently, these individuals are expected to learn this skill in the best way before they graduate. Therefore, it is thought that students with intellectual disabilities participating in the research will learn the shape of towel folding, and this research will contribute to the field since it will enable individuals to gain professional skills. The aim of this study is to determine the effectiveness of teaching with the simultaneous prompting in gaining the skill of folding towels for students with intellectual disabilities. For this purpose, answers to the following questions were sought:

1) Is the teaching method with simultaneous prompting effective in teaching students with intellectual disabilities in the ability to fold towels?

2) When the ability to fold shaped towels are taught to students with intellectual disabilities simultaneously, will the individual maintain this skill two, three, four weeks later?

3) Can students with intellectual disabilities generalize their ability to make shaped towels to different situations at the end of teaching?

4) What are the social validity findings for this intervention?

\section{Method}

\subsection{Participants}

The research was carried out with 3 students, 1 female, and 2 males, between the ages of 16-18. One of the students has moderate and two have a mild intellectual disability. All the subjects attend the vocational training center. Metin is a 16-year-old student with moderate intellectual disability. Metin has a speech disorder. Fatih is a student at the age of 18 with mild intellectual disability. Zulal is a 16-year-old student with a mild intellectual disability and a speech disorder. Fatih is quite overweight but has very short fingers and he suffers from stuttering. In determining the subjects, the individuals were expected to meet the following criteria; a) the ability to follow verbal instructions, b) paying attention to the activity for at least 5 minutes, c) using their hands, d) school attendance. Before starting the application with students with intellectual disabilities, the families were informed about the content of the research, and permission was obtained to use the camera records during the application. During the research, the real names of the subjects were not used and the code names were determined for each subject.

\subsection{Environment}

The attendance, teaching, and monitoring sessions of the research were held in a room organized in the vocational training center where the application would be held. The environment is designed just like a hotel room. There is a wardrobe at the entrance of the door, a double bed on the right, a table and chairs near the bed. Also, the room has a 
bathroom and toilet.

\subsection{Tools and Equipments}

In the research, a $30 \times 50 \mathrm{~cm}$ hand towel and $70 \times 140 \mathrm{~cm}$ bath towel was used for the sessions to be applied in teaching the students with intellectual disabilities with the simultaneous prompting of folding towel shape.

\subsection{Model of the Research}

The research was designed with a multiple baseline model with a probe between subjects, which is one of the single-subject research models. Multiple baseline model is the single-subject research pattern that aims to evaluate the effectiveness of an application on at least three dependent variables (Erbas \& Yucesoy Ozkan, 2017; Tekin-Iftar, 2012). In the probe phase, multiple probe patterns; start level data are collected simultaneously for each dependent variable. Data was collected by presenting an application to the first dependent variable, but data was not collected from the second and third dependent variables. In the first dependent variable, after reaching the performance at the criterion level during the implementation phase, the probe phase data is collected in all dependent variables. After the probe phase, the application is presented to the second dependent variable, where stable data is obtained, and after the criteria level performance is obtained, the probe phase is carried out again for all dependent variables. After obtaining criteria level performance for all three dependent variables, the study is ended by applying the probe phase for the last time (Erbas \& Yucesoy Ozkan, 2017; Tekin-Iftar \& Kırcaali-Iftar, 2017).

\subsection{Dependent Variable}

Table 1. Steps of the Skill of Making Swans with Towels

\begin{tabular}{|c|c|c|}
\hline & Skill steps $+/-$ & $+/-$ \\
\hline 1 & The individual takes the folded towel. & \\
\hline 2 & $\mathrm{~S} /$ he folds the towels. & \\
\hline 3 & S/he holds the towel by the corners of the long sides. & \\
\hline 4 & $\mathrm{~S} /$ he lays the towel on the floor. & \\
\hline 5 & $\mathrm{~S} /$ he puts both hands in the middle of the towel. & \\
\hline 6 & $\mathrm{~S} /$ he moves his hands in opposite directions. & \\
\hline 7 & S/he puts his hands on the wrinkles on the edges. & \\
\hline 8 & $\mathrm{~S} /$ he removes wrinkles by moving hands in opposite directions. & \\
\hline 9 & $\mathrm{~S} /$ he folds the towel from left to right. & \\
\hline 10 & S/he unfolds the towel. & \\
\hline 11 & S/he finds the middle point of the towel. & \\
\hline 12 & $\mathrm{~S} /$ he presses with his fingers to the midpoint of the upper edge. & \\
\hline 13 & $\mathrm{~S} /$ he holds the towel by the upper corner of the towel with his free hand. & \\
\hline 14 & $\mathrm{~S} /$ he curls the corner of the towel towards the center. & \\
\hline 15 & S/he begins to wrap the towel tightly. & \\
\hline 16 & S/he folds half of the towel. & \\
\hline 17 & $\mathrm{~S} /$ he carefully lifts his hand on the side he is wrapping. & \\
\hline 18 & $\mathrm{~S} /$ he puts the other hand in the middle of the towel. & \\
\hline 19 & S/he pulls away the hand which was initially holding the towel. & \\
\hline 20 & S/he presses the middle part of the towel thoroughly with his fingers. & \\
\hline 21 & $\mathrm{~S} /$ he holds the other top corner of the towel. & \\
\hline 22 & $\mathrm{~S} /$ he curls the corner of the towel towards the center. & \\
\hline 23 & S/he starts to wrap the towel tightly. & \\
\hline 24 & S/he wraps around half of the towel. & \\
\hline 25 & $\mathrm{~S} /$ he corrects the sharp edge formed in the towel with his fingers & \\
\hline 26 & $\mathrm{~S} /$ he reverses the towel. & \\
\hline 27 & With one hand s/he holds the pointed part and holds the loose part with the other hand. & \\
\hline 28 & S/he folds the pointed part tightly backward. & \\
\hline 29 & S/he presses the place where the curled section ends with his hand. & \\
\hline 30 & $\mathrm{~S} /$ he unfolds the pointed part that $\mathrm{s} /$ he has curled up. & \\
\hline 31 & S/he presses the pointed part forward. & \\
\hline 32 & S/he gives the towel the shape of a swan's head. & \\
\hline
\end{tabular}


In this study, the dependent variable was determined as swan making skill with a towel. Skill steps were determined by analyzing the skill to be taught within the scope of the research. The steps of the skill of making swans with a towel are presented in Table 1. The single -opportunity method was used to determine the performance levels of the subjects towards target behavior.

\subsection{Independent Variable}

Model + verbal prompt and error correction was used as the independent variable of this research with the simultaneous prompting using a physical prompt. Experimental control in multiple probes patterns as evidenced by the absence of changes in baseline levels without application (Erbas \& Yucesoy Ozkan, 2017). In this study, experimental control was provided by experimental control, the data obtained from the subjects who were trained at the end of the education increased compared to the baseline level and that the subjects who were not trained show data similar to the data obtained at the start level.

\subsection{Implementation Process}

The prompt to be presented to the subjects before the implementation process is planned. The prompt is presenting to the student what to do and how to do that in the presence of a certain stimulus (Varol, 2006). There are two types of prompts: the controller prompt and the non-controller prompt. Tekin (1999) made the controlling prompting that the student responded correctly; defines the non-controlling clue as to a prompt that increases the probability of the student taking the correct reaction but is not certain. The controlling prompt is the physical prompt that makes sure that the subjects respond correctly. Verbal prompt and model prompt are clues that increase the probability of the subjects to react correctly but do not make it certain. In the research, the use of two types of prompt has been included.

While the model + verbal prompt is determined as the controller prompt in the research, error correction is the physical prompt. First, it became a model by applying the practitioner skill steps regarding how to perform the shaped towel folding skills to the subjects. When the subject could not do the skill steps according to the specified criteria, the physical prompt was used as error correction and the subject was asked to do the skill step. In the study, the directive, "Make swans with towels" was given to allow the subject to react.

How to respond to the correct and incorrect responses of the subject was also determined before starting the teaching. The practitioner constantly reinforced all the correct reactions before and after the subject's prompt during the application process. "Follow me carefully" was given as a warning to prevent the subject from responding incorrectly before the controller prompt. If the subject responded incorrectly after the prompt, the physical prompt was used by intervening, and error correction was made. The fact that the subject did not react was ignored and error correction was made, and the physical prompt was used. Data was collected by using "Collective Probe, Generalization, and Maintaining Sessions Skill Analysis Data Registration Form", "Teaching Sessions Application Reliability Data Collection Form" in the probe monitors, and generalizations sessions of the research.

In this study, the effectiveness of teaching was tested with the simultaneous prompting in the teaching of shaped towel folding skills. The applications were carried out one-to-one with three subjects. Attendance, teaching, monitoring, and generalization sessions were organized for each subject. Collective probe sessions were held simultaneously before starting instruction to collect baseline data and follow-up metering criteria in each subject. No prompt was provided to the subjects in the probe sessions. Data from probe sessions were collected using the single opportunity method.

Attendance Sessions: Firstly, the subject was provided to direct his attention to the study. For the ability to make a swan with a towel from the shaped towel folding skills, the following instruction was given: 'Now we will work with you to make swan with a towel. Are you ready? "Following that, the subject's attention was directed to the study. When the subject stated being ready for practice, the practitioner said, "Great! You are ready for practice." and motivated the subject. Then, the subject was given the skill instruction "Make swans with towels." The subject was kept waiting for 5 seconds to start the first step of the skill analysis. When the subject performed the first step of the skill analysis correctly, a (+) sign was placed on the registration form, and it was observed whether the subject started the next step within 5 seconds. When the subject was unable to perform the first step of the skill analysis correctly, the probe session was ended by placing a (-) sign on the registration form. After the skill, instruction was submitted or the previous step has been completed correctly if the subject did not respond within 5 seconds, the probe session was ended by placing the mark (n.r) in the non-response column in the registration form.

All the correct responses of the subjects in the probe sessions were verbally reinforced with a continuous reinforcement schedule. When all the responses were corrected in the batch probe sessions, a badge was given as a symbol of approval. Presenting a badge as reinforcement was found appropriate regarding learning the skill as the subjects with intellectual disabilities were rewarded using this method. Also, it has been found appropriate to give money to the 
subjects in return for the work they had completed. In addition to the badge, the participants were given 1 Turkish Lira. At the end of the batch probe sessions, the number of steps where the subject reacted correctly was divided by the total number of skill steps. The percentage of the steps that each subject made correctly was found and plotted.

Teaching Sessions: First, to provide the subject's attention to the study, the prompt was presented as "I am ready to start working if you are ready." Skill instruction was presented to the subject as "Make a swan with the towel." Verbal + model prompt was given together immediately after the skill instruction was given. Next, the subject was told to do the step which said "Now take the towel that has been folded." 5 seconds were allowed for the subject to respond. When the subject performed the step correctly, he was verbally reinforced by saying, "Well done, you have folded the towel correctly." In case the subject responded incorrectly, a physical prompt was used as error correction. All correct responses of the subjects in the teaching sessions were verbally reinforced using the continuous reinforcement schedule. The fixed-rate reinforcement schedule was used in the teaching session after the criterion was met, and the fixed-rate reinforcement schedule was used in the last education session. In subject probe sessions, teaching sessions were terminated when three sessions of $100 \%$ criteria were met consecutively.

Generalization and Maintaining Sessions: Generalization sessions were held in a different environment, at different times and using different equipment. The sessions were held between 14.00-14.35 at the central training center's accommodation workshop using different towels. Sessions were held as face-to-face instruction. In the generalization sessions, the correct responses of the students were reinforced using the fixed-rate reinforcement schedule, while the incorrect responses of the students were left unresponsive and the study was completed.

After the education was completed, maintaining sessions were held to study the maintenance of the subjects learned during education. Following the end of the teaching sessions, maintenance sessions were held at 2, 3, and 4-week intervals and were carried out as collective probe sessions. The correct responses of the students were verbally reinforced using the continuous reinforcement schedule.

\subsection{Reliability}

In the study, inter-observer reliability and application reliability data were collected. Video records were used in collecting reliability data. Observers watched $30 \%$ of the video records selected from the video recordings and recorded them on the prepared recording forms. In calculating inter-observer reliability, the formula " consensus / [consensus + divergence] x100 was used. Inter-observer reliability was calculated as $96 \%$. Data collected from application reliability was calculated with the formula "observed practitioner behavior / planned practitioner behavior X 100." Application reliability was calculated as $98 \%$.

\subsection{Social Validity}

To collect social validity data of this research, Social Validity Questionnaire was prepared and the opinions of the subjects were taken. The Social Validity Questionnaire included questions such as whether they love learning how to fold a towel in the shape, whether learning this skill will be beneficial in business life, whether they want to participate in a similar study, whether they recommend teaching the skill to other friends using the same method.

\subsection{Data Analysis}

The data obtained in the study was evaluated based on the graphical analysis. The graphical analysis ensures that the performance of the individual is seen realistically, and ensures that necessary changes are made in the implementation process and enables the practitioner to provide effective feedback to the individual (Tekin Iftar \& Kurcaali Iftar, 2017). Attendance, teaching, and monitoring sessions on the chart are presented on the horizontal axis; the correct display of target behavior is shown on the vertical axis.

\section{Findings}

The data obtained from all subjects in the teaching of shaped towel folding skills using the simultaneous prompting teaching method is shown in Figure 1. 

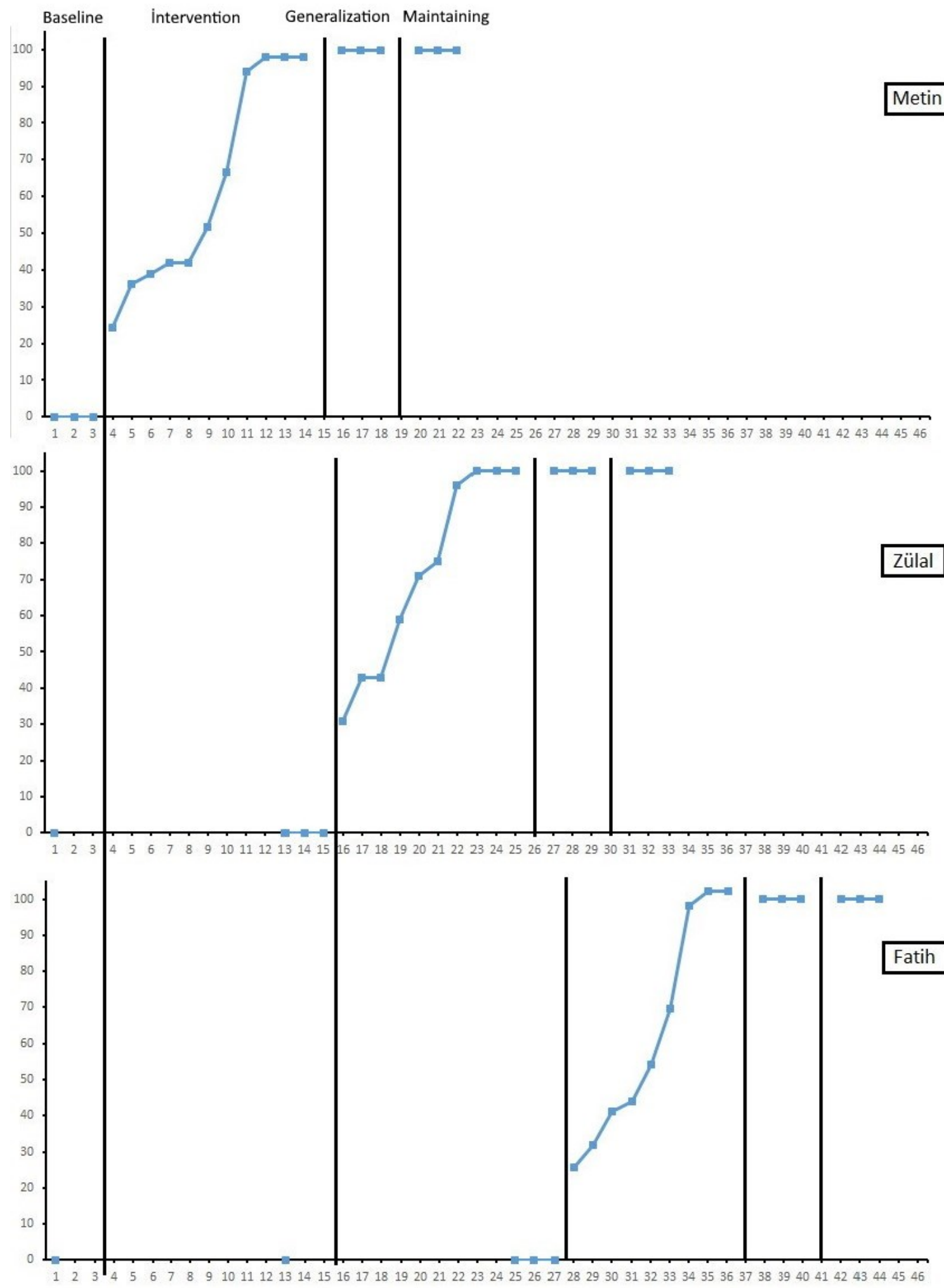

Figure 1. The Correct Behavioral Percentages Regarding the Ability to Make Swans with Towels for Metin, Zulal, and Fatih with the Simultaneous Prompting Teaching Method 
Metin (Student 1) made a correct response at the level of $0 \%$ in baseline prior to the teaching of the shaped towel folding skills. In the probe stage on the first day of the implementation phase, $25 \%$ of the skill step consisting of thirty-two steps of the towel making swan making skill were carried out correctly. Metin was able to complete ten steps $(31.25 \%)$ in the second probe session, thirteen steps $(40.62 \%)$ in the third probe session, fourteen steps $(43.75 \%)$ in the fourth probe session, and ten in the fifth probe session four steps $(43.75 \%)$, seventeen steps in the sixth probe session $(53.12 \%)$, twenty-two steps $(68.75 \%)$ in the seventh probe session, thirty-three steps $(96 \%)$ in the eighth probe session accurately. In the ninth session, he performed all the thirty-two steps correctly and performed the skill steps with $100 \%$ accuracy. It was observed that Metin performed the skill of making swan with towels at $100 \%$ accuracy in all the sessions held at the end of the implementation process.

Zulal (Student 2) responded correctly at the level of $0 \%$ for shaped towel folding in baseline. In the probe session on the first day, she carried out $31.25 \%$ of the skill steps consisting of thirty-two steps of a towel and swan making correctly. Zulal was able to complete fourteen steps $(43.75 \%$ of them) in the second probe session, fourteen steps ( $43.75 \%$ of them) in the third probe session, nineteen steps $(59.37 \%$ of them) in the fourth probe session, twenty-three steps in the fifth probe session (71. 87\%), twenty-four steps (75\%) in the sixth probe session, and thirty-one steps (96\%) in the seventh probe session accurately. In the eighth session, she performed all the thirty-two steps correctly and performed the skill steps with $100 \%$ accuracy. It was observed that Zulal had acquired the ability to make swan with towels in $100 \%$ accuracy in all the sessions held at the end of the implementation process.

Fatih (Student 3) made the correct response at the level of $0 \%$ in the baseline stage prior to the teaching of the towel-shaped folding skill. In the attendance of the session on the first day, he was able to carry out $25 \%$ of the skill step consisting of thirty-two steps of a towel and swan making skill correctly. Fatih was able to complete twelve steps $(37.5 \%)$ in the second probe session, thirteen steps $(40.62 \%)$ in the third probe session, fourteen steps $(43.75 \%)$ in the fourth probe session, as well as four steps in the fifth poll session (43.75\%), seventeen steps in the sixth probe session $(53.12 \%)$, twenty-two steps $(68.75 \%)$ in the seventh probe session, thirty-three steps $(96 \%)$ in the eighth probe session accurately. In the ninth session, he performed all the thirty-two steps correctly and performed the skill steps with $100 \%$ accuracy. It was observed that Fatih had acquired the ability to make swans with towels at $100 \%$ accuracy in all the sessions held at the end of the implementation process.

The generalization data of the research were collected prior to and following the teaching ended with the pretest-posttest model. According to the data obtained using the single opportunity method, it was determined that the persistence of the shaped towel folding ability in all three monitors sessions continued $100 \%$ in all three subjects. The ability to fold towels using the teaching method with the simultaneous prompting for Metin is $0 \%$ in the pre-test session and $100 \%$ in the post-test session; It was observed that Zulal was generalized at the level of $0 \%$ in the pretest session, $100 \%$ in the posttest session, whereas $0 \%$ in the pretest session for Fatih and $100 \%$ in the posttest session.

\section{Discussions, Conclusions, and Suggestions}

The aim of this study was to find out whether the teaching method with simultaneous prompting using the physical prompt as error correction is effective in teaching students of intellectual disability to shape towel shaping skill, and to determine whether the students could continue the skill two, three, and four weeks after the education ended and if they could generalize the shaped towel folding skill to different situations. Another purpose was to determine the social validity of the research by taking the opinions of the subjects. It is aimed to gain independent living skills in education provided to individuals with intellectual disabilities because their independent lives are linked with their quality of life and life satisfaction (Diken \& Bakkaloglu, 2016). Independent life skills include maintaining an individual's own life by having a job, and financial gain. Deutsch Smith (2007) has stated that if individuals with intellectual disabilities have a job, this contributes to these individuals providing economic income, developing friendship relationships, being involved in social activities, and ensuring their satisfaction in life.

Findings obtained from the research shows that teaching students with intellectual disabilities are effective in the teaching of shaped towel folding skills and that the subjects maintain the ability to fold towels following training and continue the skill after two, three, and four weeks. It was seen that subjects could generalize to different towels. Generalization findings show that all three subjects can generalize their $100 \%$ level towel folding ability to different towels. When the researches are examined, the concurrent clue shows that teaching method is effective in teaching skills to students with intellectual disabilities and its permanence is preserved after teaching ends (Cankaya, 2011; Fetko, Schuster, Harley, \& Collins, 1999; Leblebici, 2012; Schuster \& Griffen, 1993).

According to the findings obtained from the research, there is an increase in the shaped towel folding performance of the subjects from the first session onward. This finding is similar to the results of the research showing that teaching is 
effective in teaching skills to individuals with intellectual disabilities. Aslan and Eratay (2009) to teach stamp processing skills; Ozbey (2005) the teaching business skills; Yucesoy (2002) to gain the ability to make copies; Schuster and Griffen (1993) tested the effectiveness of teaching with the simultaneous prompting to teach the ability to prepare concentrated juice.

In this study, it is possible to associate the fact that the teaching with the simultaneous prompting is effective in the shape of the towel folding skills because of the subjects provide the prerequisite skills, the skill targeted to be taught is suitable for the school's curriculum, and that the teaching of skill to meet the needs is chosen. However, the correct responses of the subjects in the probe sessions and teaching sessions were reinforced using the continuous reinforcement schedule. It is important to give badges and money as reinforcement for the subjects to learn that they can be earned as the price of their work when they perform their ability to make shaped towels in real environments. In similar studies, it is seen that money is used as reinforcement, and it is emphasized that it is important for learning that money is earned for the job (Aslan, 2009; Topsakal \& Duzkantar, 2009).

According to another finding obtained from the research, it was seen that the general answers of the subjects were positive to the questionnaire developed to determine the social validity of the research. All the subjects stated that they liked to learn the shape of a folding towel; they thought that learning this skill would be beneficial in business life, they wanted to participate in another similar study and the skill should be taught to other friends using the same method.

In this study, the effectiveness of teaching with the simultaneous prompting in the teaching of shaped towel folding skills to students with a intellectual disabilities was examined. In the teaching of different skills that will contribute to the acquisition of professions for students with intellectual disabilities, researches with students of different age groups and different types of disabilities can be designed.

\section{References}

AAMR. (2002). Mental retardation: Definition, classification, and systems of support. Washington: AAMR.

Aslan, T. (2009). Zihin engelli bireylere elektrikli çim biçme makinesiyle çim biçme becerisi ogretiminde es zamanlı ipucuyla ogretimin etkililigi [The efficacy of teaching with simultaneous prompting in teaching of the skill of mowing with electrical mower to individuals with mental retarded] (Master thesis). Abant İzzet Baysal University, Bolu. Retrieved from https://tez.yok.gov.tr/UlusalTezMerkezi/tezSorguSonucYeni.jsp

Aslan, Y., \& Eratay, E. (2009). Zihin engelli bireylere kumas uzerine çizilen desene pul isleme becerisinin ogretiminde es zamanlı ipucuyla ogretimin etkililigi [The effectiveness of teaching with simultaneous prompting in teaching the skill of sequin embroidering on a pattern drawn on fabric for individuals with mental disability]. Ankara Universitesi Egitim Bilimleri Fakultesi Ozel Egitim Dergisi, 10(2), 15-34. https://doi.org/10.1501/Ozlegt_0000000138

Avcioglu, H. (2018). Ozel egitimde sosyal uyum becerilerinin ogretimi [Teaching social adaptation skills in special education]. Ankara: Educating Book.

Brady, M. P., \& Rosenberg, H. (2002). Job observation and behavior scale: A supported employment assessment instrument. Education and Training in Mental Retardation and Developmental Disabilities, 37, 427-433. https://doi.org/10.1037/t06060-000

Cankaya, O. (2011). Zihin engelli ogrencilere harosa orgu orme becerisinin ogretiminde es zamanl ipucuyla ogretimin etkililigi [Effectuality of teaching with simultaneous prompting to teach the skill of stockinette stitch to students with mental retarded] (Master thesis). Abant İzzet Baysal University, Bolu. Retrieved from https://tez.yok.gov.tr/UlusalTezMerkezi/tezSorguSonucYeni.jsp

Ciftci Tekinarslan, İ., \& Uçar Rasmussen, M. (2017). Zihinsel yetersizligi olan ogrencilere yemek masası hazırlama becerisinin ogretiminde es zamanlı ipucuyla ogretimin etkililigi [Effectiveness of simultaneous prompting in the teaching of table setting skills to students with intellectual disabilities]. Education Sciences (NWSAES), 12(4), 147-162.

Deutsch-Smith, D. (2007). Introduction to special education: Making a difference. Boston: Pearson Education Inc.

Diken, İ. H. (Ed.). (2015). Ozel ĕgitime gereksinimi olan oğrenciler ve ozel eğitim [Students with special needs and special education] (12th ed.). Pegem Academy Publishing: Ankara.

Diken, İ. H., \& Bakkaloglu, H. (2016). Zihin yetersizligi ve otizm spektrum bozuklugu [Mental insufficiency and autism spectrum disorder]. Ankara: Pegem Academy. 
Erbas, D., \& Yucesoy Ozkan, S. (2017). Uygulamalı davranıs analizi [Applied behavior analysis]. Ankara: Pegem Academy.

Fetko, K. S., Schuster, J. W., Harley, D. A., \& Collins, B. C. (1999). Using simultaneous prompting to teach a chained vocational task to young adults with severe intellectual disabilities. Education and Training in Mental Retardation and Developmental Disabilities, 34(3), 318-329.

Jacob, A., Scott, M., Falkmer, M., \& Flakmer, T. (2015). The costs and benefits of employing an adult with autism spectrum disorder: A systematic review. PLOS ONE, 10(10), 1-16. https://doi.org/10.1371/journal.pone.0139896

Kroese, B. S., Kuljit, J. R., \& O’Brien, H. A. (2013). Gender issues for people with intellectual disabilities and mental health problems: Asking what service users and staff think. Advances in Mental Health and Intellectual Disabilities, 7(4), 181-190. https://doi.org/10.1108/AMHID-03-2013-0021

Leblebici, T. (2012). Zihinsel engelli ogrencilere galos yapma becerisinin ogretiminde es zamanl ipucuyla ogretimin etkililigi [The effectiveness of simultaneous prompting on teaching making overshoe skills to students with mental disabilities] (Master Thesis). Dokuz Eylul University, Izmir. Retrieved from https://tez.yok.gov.tr/UlusalTezMerkezi/tezSorguSonucYeni.jsp

Lewis, G., Thoresen, S. H., \& Cocks, E. (2011). Successful approaches to placing and supporting apprentices and trainees with disability in Australia. Journal of Vocational Rehabilitation, 34(3), 181-189.

Maciag, K. G., Schuster, J. W., Collins, B. C., \& Cooper, J. T. (2000). Training adults with moderate and severe mental retardation in vocational skill using a simultaneous prompting procedure. Education and Training in Mental Retardation and Developmental Disabilities, 35(3).

Matson, J. L., Rivet, T. T., Fodstad, J. C., Dempsey, T., \& Boisjoli, J. A. (2009). Examination of adaptive behavior differences in adults with autism spectrum disorders and intellectual disability. Research in Developmental Disabilities, 30, 1317-1325.

Ministry of National Education Vocational Technical Education General Directorate. (2013). The analysis of educational needs of people requiring special policy project on improving professional skills research report. Ankara: MEB.

Ministry of National Education. (2007). Accommodation, and travel services housekeeping organization strengthening vocational education and training system project. Ankara.

Ministry of National Education. (2018). Special education services regulation. Retrieved from https://www.resmigazete.gov.tr/eskiler/2018/07/20180707-8.htm

Myklebust, J. O. (2013). Disability and adult life: Dependence on social security among former students with special educational needs in their late twenties. British Journal of Special Education, 40, 5-13.

Odluyurt, S. (2015). Kaynastırma egitiminde uygulamalı davranıs analizi [Applied behavior analysis in inclusive education]. Ankara: Educating Book.

Schalock, R. L., Luckasson, R. A., \& Shogren, K. A., et al. (2007). The renaming of mental retardation: Understanding the change to the term intellectual disability. Intellectual and Developmental Disabilities, 45(2), 116-124.

Schuster, J. W., \& Griffen, A. K. (1993). Teaching a chained task with a simultaneous prompting procedure. Journal of Behavioral Education, 3, 299-315.

Sucuoglu, B. (2012). Zihin engelliler ve egitimleri [Mentally handicapped and their education]. Ankara: Root Publishing.

Tekin İftar, E., \& Kırcaali Iftar, G. (2017). Ozel egitimde yanlisslz ogretim yontemleri [Accurate teaching methods in special education]. Ankara: Vize Publishing.

Tekin, E. (1996). Etkili ve islevsel bireyselleştirilmiş eğitim programlarının hazırlanması. [Preparation of effective and functional individualized education programs]. Anadolu Universitesi Egitim Fakultesi Dergisi, 6, 111-122.

Tekin, E. (2000). Zihin ozurlu çocuklara kardeşleri aracılığıyla sunulan dort saniye sabit bekleme sureli oğretimin ve eşzamanl ipucuyla oğretimin etkililiklerinin ve verimliliklerinin karşılaştırılması [Comparing the effectiveness and efficiency of $4 \mathrm{sec}$ constant time delay and simultaneous prompting procedures delivered to children with mental retardation by their siblings]. Eskisehir: Anadolu University Publishing. 
Rasmussen, M. U., \& Tekinarslan, İ. Ç. (2017). Zihinsel yetersizliği olan öğrencilere yemek masasi hazirlama becerisinin öğretiminde eşzamanli ipucuyla öğretimin etkililiği. [The effectiveness of teaching with the simultaneous hint in teaching the skill of preparing a table for students with mental disabilities]. Education Sciences, 12(4), 147-162. https://doi.org/10.12739/NWSA.2017.12.4.1C0675

Topsakal, M., \& Duzkantar, A. (2010). Zihin ozurlu çocuklara oto yıkama becerisi oğretiminde hata duzeltmesi yapılarak gerçekleştirilen eşzamanlı ipucuyla oğretimin etkililiği [The Effectiveness of Simultaneous prompting in teaching car washing to children with mental retardation by correcting error]. Abant Izzet Baysal Universitesi Dergisi, 10(2), 79-94.

Varol, N. (2006). Beceri ogretimi ve oz bakım becerilerinin kazandırllması [Teaching skills and self-care skills]. Ankara: Root Publishing.

Wehman, P. (1996). Life beyond the classroom: Transition strategies for young people with disabilities. Baltimore: Paul H. Brookes Publishing Co.

Wehman, P., \& Kregel, J. (2004). Functional curriculum for elementary, middle, and secondary age students with special needs. PRO-ED, Inc. 8700 Shoal Creek Blvd, Austin.

Winn, S., \& Hay, I. (2009). Transition from school for youths with a disability: Issues and challenges. Disability and Society, 24, 103-115.

\section{Copyrights}

Copyright for this article is retained by the author(s), with first publication rights granted to the journal.

This is an open-access article distributed under the terms and conditions of the Creative Commons Attribution license (http://creativecommons.org/licenses/by/4.0/). 